\title{
UNUSUAL MORPHOLOGIES OF Cryptococcus spp. IN TISSUE SPECIMENS: REPORT OF 10 CASES
}

\author{
Alexandra Flávia GAZZONI(1), Flávio de Mattos OLIVEIRA(2), Emily Ferreira SALLES(3), Emilio MAYAYO(1,4), Josep GUARRO(5), \\ Javier CAPILLA(5) \& Luiz Carlos SEVERO(2,6,7)
}

\begin{abstract}
SUMMARY
Ten cases of cryptococcosis due to unusual microscopic forms of Cryptococcus sp. observed over a twenty-eight year period (1981-2009) are presented. The most important clinicopathological and laboratory data are tabulated. The uncommon forms of cryptococcal cells given are: structures resembling germ tube (one case), chains of budding yeasts (one case), pseudohyphae (two cases) and nonencapsulated yeast-like organisms (eight cases). The diagnosis was based on the histopathological findings. The causative organism was isolated and identified in seven cases; five were due to C. neoformans, and two to C. gattii. In addition, the importance of using staining histochemical techniques - Grocott's silver stain (GMS), Mayer's mucicarmine stain (MM) and Fontana-Masson stain (FM) - in the diagnosis of cryptococcosis is argued.
\end{abstract}

KEYWORDS: Cryptococcosis; Pseudohyphae; Chains of budding yeasts; Germ tube-like structures; Nonencapsulated yeast-like organisms.

\section{INTRODUCTION}

In clinical specimens, Cryptococcus species are usually identified as spherical-to-oval yeast cells, range from 4-20 $\mu \mathrm{m}$ in diameter, and are surrounded by a mucopolysaccharide capsule, which is a major virulence factor ${ }^{5,14}$. Single or multiple budding cells with a narrow base are usually observed ${ }^{14}$. In addition to these classical aspects, Cryptococcus may also be present in unusual forms, which include pseudohyphae $e^{1,7}$, chains of budding yeasts ${ }^{7,27}$, structures resembling germ tubes ${ }^{7}$ and poorly encapsulated cells ${ }^{8}$.

Histopathological identification of the cryptococcosis is based on the micromorphological and staining features of the cryptococcal cells, and include histochemical techniques of hematoxylin and eosin (HE), and Grocott's silver stain (GMS), as well as special histochemical techniques such as Mayer's mucicarmine method (MM), which stains the capsule magenta, and Fontana-Masson procedure (FM), which stains fungal melanin reddish-brown ${ }^{7,8}$.

In this study, we highlight the unusual micromorphological forms of the Cryptococcus species in tissue specimens. It also emphasizes the use of histochemical techniques in the diagnosis of cryptococcosis.

\section{MATERIAL AND METHODS}

Through database analysis, we retrospectively reviewed all cases of cryptococcal infections diagnosed between January 1981 and May 2009 at the Mycology Laboratory of Santa Casa Complexo Hospitalar (Porto Alegre, RS), in Southern Brazil.

Clinical-epidemiological and laboratory records of the cases diagnosed by histopathological examination were reviewed, and we were primarily interested in collecting data such as: sex, age, underlying diseases, titers of cryptococcal antigens $(\mathrm{CrAg})$ in sera, urine and cerebrospinal fluid (CSF) and species of Cryptococcus recovered in cultures.

Cultures: The identification was confirmed by: (a) colony morphology - by isolation of yeast colonies with white mucoid aspect (depending on the capsule thickness) after cultivation on fungal media (within 48-72 h), namely Sabouraud's (SAB) at $25^{\circ} \mathrm{C}$, and brain-heart infusion (BHI) agar at $35^{\circ} \mathrm{C}$; (b) microscopy morphology - by demonstration of spherical-tooval encapsulated yeast cells and budding on a narrow base. After identity of an isolate had been established, such as Cryptococcus, we proceeded to determine its species status. Canavanine-glycine-broothymol blue (CGB) agar was successfully used for this purpose. In one to five days, isolates of $C$. gattii cause the CGB medium to turn blue, whereas those of C. neoformans do not.

CrAg detection: For serological diagnosis, latex agglutination for cryptococcal polysaccharide antigens was perfomed a specific and sensitive alternative for rapid diagnosis. In this study, the commercial kit IMMY test was used, which has a vital component in Detacher Enzyme (DE), Pronase ${ }^{\circledR}$. DE eliminates the rheumatoid factor, which can produce false positives. 
GAZZONI, A.F.; OLIVEIRA, F.M.; SALLES, E.F.; MAYAYO, E.; GUARRO, J.; CAPILLA, J. \& SEVERO, L.C. - Unusual morphologies of Cryptococcus spp. in tissue specimens: report of 10 cases. Rev. Inst. Med. Trop. Sao Paulo, 52(3):145-9, 2010.

Histopathological studies: Fragments obtained through biopsy or surgical excision were fixed in formalin, embedded in paraffin and, after sectioned, stained for evaluation. The histopathological examination was made on routine HE preparations to determine organ involvement by fungal pathogen and to determine details of tissue response. In all cases, tissue sections stained with selective staining such as GMS, MM and FM were examined.

\section{RESULTS}

Between 1981 and 2009, 925 patients with cryptococcosis were diagnosed in our mycology laboratory, with 33 cases being established through histopathological diagnosis.

In a total of 10 out of these 33 cases unusual microscopic forms of Cryptococcus were observed. Gender distribution showed a predominance of males ( $70 \%$ - 7/10), and the mean age was 42.4 years old (range, 23 - 60 years). Table 1 summarizes the clinical and pathological data for the 10 patients. With the exception of three immunocompetent patients, the remaining patients had the following underlying diseases: AIDS (three cases), kidney and lung transplantation (two cases and one case, respectively), and lymphoma (one case).

Cryptococcal antigen detection: $\mathrm{CrAg}$ test of patients showed titres ranging from 1:5112 to 1:1048576. In six cases (60\%), CrAg test was negative.

Identification of cultures: Cryptococcus isolated from these patients was identified as species neoformans in five cases (50\%). Cryptococcus gattii was recovered from an immunocompetent patient and from a patient with AIDS. In three cases, the identification from cultures - on fungal media, namely SAB, BHI and CGB - was not performed due to biopsy specimens being in formalin fixation.

Histopathological findings: Histologically, Cryptococcus was found in multiple organs (lungs, brain, liver, cervical and axillary lymph nodes and left axillary region). The lungs were the organs most often involved (cases 1-3, 5 and 8) (50\%-5/10).

In cases 4, 6, 9 and 10, HE staining followed by microscopic examination showed usual rounded refractile bodies with a surrounding halo, accompanied by minimal, predominantly lymphatic infiltration. These paucireactive patterns were associated with complete replacement of host tissue by extracellular yeasts and mucin (Fig. 1A). The cases

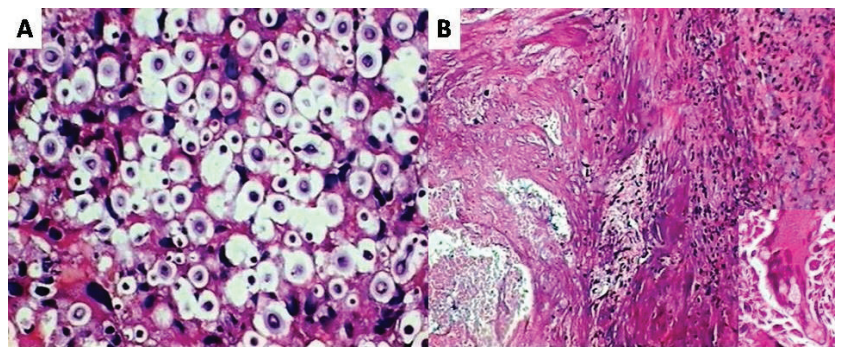

Fig. 1 - A, Left axillary tumor biopsy with paucireactive cryptococcosis. Numerous yeast-like organisms are surrounded by clear halos representing gelatinous capsules stained with HE (case 4) (x 10). B, Lung biopsy with reactive cryptococcosis. Granulomatous inflammation with necrosis, fibroblastic activity and foreign-body giant-cells (case 3) (x10).
1-3, 5, 7 and 8 were characterized by a marked granulomatous response composed predominantly of histiocytes, multinucleated giant cells, and lymphocytes in which cryptococci were predominantly intracellular (phagocytosis). These reactive patterns were associated with fibrosis (Fig. 1B).

In cases 4 and 6, staining with GMS revealed black organisms on a light green background - numerous spherical-to-oval yeasts were surrounded by a narrow, circumferential, refractile zone of negative staining (halos) (Fig. 2A).

Several uncommon micromorphologies of Cryptococcus were identified. These included germ tube-like structures (one case), chains of budding yeasts (one case), pseudohyphae (two cases) and nonencapsulated yeast-like organisms (eight cases).

Nonencapsulated yeast-like organisms were observed in cases 1-3, 5 and 7-10. The numerous fungal cells were stained strongly with GMS, although encapsulation was not evident (pericellular clear zone absent) (Fig. 2B).

Germ tube-like structures were seen in case 6 (Fig. 2C). However, these possessed a constriction at their base at the point of attachment to the adjacent yeasts. Chains of budding yeasts were also observed in this case (Fig. 2D). In spite of having a pseudohyphae-like appearance, the individual cells did not possess the characteristic elongation of typical pseudohyphae.

In cases 4 and 6, the MM staining strongly stained the capsules with a deep magenta color, consistent with the presence of mucopolysaccharides. Although many of the yeasts were arranged singly, some demonstrated narrow-based budding, and a few clusters of yeasts with multiple budding were seen. In these cases, pseudohyphae were seen that varied in size. In several instances, these elongated structures, consistent with pseudohyphae, were seen in continuity with a chain of budding

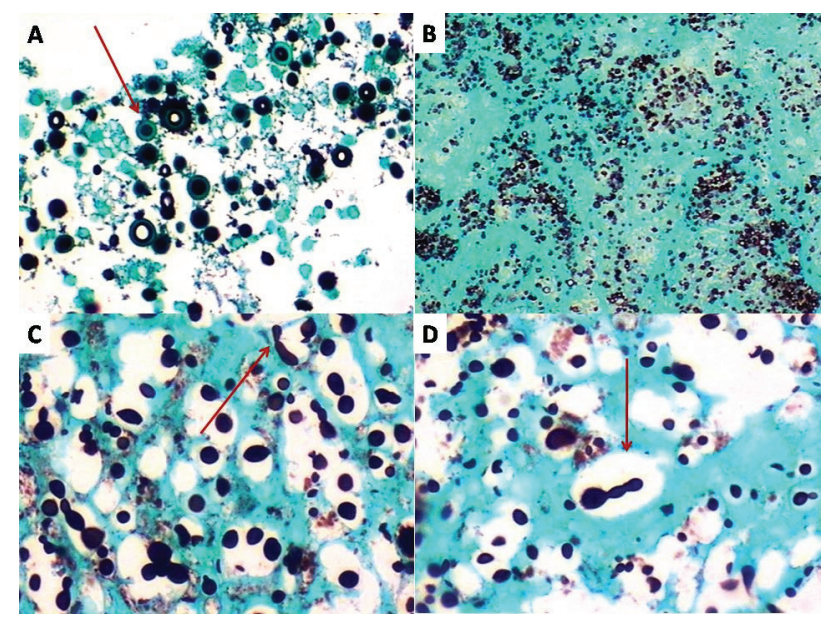

Fig. 2 - A, Left axillary tumor biopsy stained with GMS stain. Capsulated morphology of yeast-like fungal bodies; some structures exhibit narrow-based budding (case 4) (x10). B, Pulmonary cryptococcosis. Nonencapsulated fungal morphologies are observed. Fungal cell wall is stained in black (case 2) (x10). C, Cervical lymph node tissue. Germ tube-like structure; constriction at the base is evident (case 6) (x 10). D, Cervical lymph node tissue. Budding yeasts arranged in chains (case 6) (x 10). 


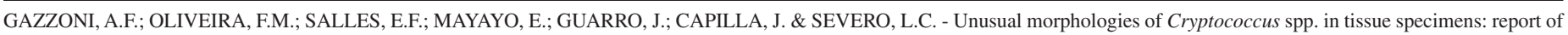
10 cases. Rev. Inst. Med. Trop. Sao Paulo, 52(3):145-9, 2010.

Table 1

Clinicopathologic summary of cases which presented unusual morphologies of Cryptococcus species in tissue specimens at Mycology Laboratory, Complexo Hospitalar/Santa Casa

\begin{tabular}{|c|c|c|c|c|c|c|c|c|c|}
\hline $\begin{array}{l}\text { Cases } \\
\text { [Ref.] }\end{array}$ & $\begin{array}{l}\text { Sex, } \\
\text { Age }\end{array}$ & $\begin{array}{l}\text { Underlying } \\
\text { diseases }\end{array}$ & $\begin{array}{l}\text { Tissue site } \\
\text { (type of } \\
\text { specimens) }\end{array}$ & $\begin{array}{l}\text { Histologic } \\
\text { pattern }\end{array}$ & Grocott's silver stain & $\begin{array}{l}\text { Mayer's } \\
\text { mucicarmine } \\
\text { stain }\end{array}$ & $\begin{array}{l}\text { Fontana-Masson } \\
\text { stain }\end{array}$ & $\begin{array}{l}\mathrm{Cr} \mathrm{Ag} \\
\text { titers }\end{array}$ & $\begin{array}{l}\text { Identification } \\
\text { of culture }\end{array}$ \\
\hline $1[8]$ & $\mathrm{F}, 42$ & $\begin{array}{l}\text { Immunocompetent } \\
\text { patient }\end{array}$ & Lung & Reactive & $\begin{array}{l}\text { Nonencapsulated } \\
\text { yeast-like within } \\
\text { multinucleated giant } \\
\text { cells }\end{array}$ & Negative & Positive & Negative & NA \\
\hline 2 & $\mathrm{~F}, 40$ & $\begin{array}{l}\text { Immunocompetent } \\
\text { patient }\end{array}$ & Lung & Reactive & $\begin{array}{l}\text { Nonencapsulated } \\
\text { yeast-like }\end{array}$ & Negative & Positive & Negative & NA \\
\hline 3 & M, 59 & Lung transplant & Lung & Reactive & $\begin{array}{l}\text { Nonencapsulated } \\
\text { yeast-like within } \\
\text { multinucleated giant } \\
\text { cells }\end{array}$ & Negative & Positive & Negative & NA \\
\hline 4 & M, 56 & $\begin{array}{l}\text { Immunocompetent } \\
\text { patient }\end{array}$ & $\begin{array}{l}\text { Left axillary } \\
\text { region }\end{array}$ & Paucireactive & $\begin{array}{l}\text { Spherical-to-oval } \\
\text { yeasts-like with } \\
\text { pericellular clear halos } \\
\text { Pseudohyphae }\end{array}$ & $\begin{array}{l}\text { Fungal cell with } \\
\text { magenta capsule } \\
\text { Chains of budding } \\
\text { yeasts }\end{array}$ & $\begin{array}{l}\text { Positive } \\
\text { Classical aspects } \\
\text { of Cryptococcus }\end{array}$ & $1: 5112^{a}$ & C. gattii $^{c}$ \\
\hline 5 & M, 60 & Lymphoma & Lung & Reactive & $\begin{array}{l}\text { Nonencapsulated } \\
\text { yeast-like }\end{array}$ & Negative & Positive & NA & C. neoformans ${ }^{d}$ \\
\hline \multirow[t]{2}{*}{$6[7]$} & M, 29 & AIDS & $\begin{array}{l}\text { Cervical } \\
\text { lymph node }\end{array}$ & Paucireactive & $\begin{array}{l}\text { Spherical-to-oval } \\
\text { yeast-like with } \\
\text { pericellular clear } \\
\text { halos } \\
\text { Germ tube-like } \\
\text { structures } \\
\text { Pseudohyphae } \\
\text { Chains of budding } \\
\text { yeasts }\end{array}$ & $\begin{array}{l}\text { Fungal cell with } \\
\text { magenta capsule, } \\
\text { Pseudohyphae } \\
\text { Chains of budding } \\
\text { yeasts }\end{array}$ & $\begin{array}{l}\text { Positive } \\
\text { Classical aspects } \\
\text { of Cryptococcus }\end{array}$ & $\begin{array}{l}1: 1.048 .576^{a} \\
1: 4096^{b}\end{array}$ & C. neoformans ${ }^{d}$ \\
\hline & & & $\begin{array}{l}\text { Tongue } \\
\text { biopsy }\end{array}$ & Paucireactive & $\begin{array}{l}\text { Spherical-to-oval } \\
\text { yeast-like with } \\
\text { pericellular clear halos }\end{array}$ & $\begin{array}{l}\text { Fungal cell with } \\
\text { magenta capsule }\end{array}$ & $\begin{array}{l}\text { Positive } \\
\text { Classical aspects } \\
\text { of Cryptococcus }\end{array}$ & & \\
\hline 7 & M, 40 & Kidney transplant & Skin & Reactive & $\begin{array}{l}\text { Nonencapsulated } \\
\text { yeast-like }\end{array}$ & Negative & Positive & Negative & C. neoformans ${ }^{d}$ \\
\hline 8 & M, 42 & Kidney transplant & Lung & Reactive & $\begin{array}{l}\text { Nonencapsulated } \\
\text { yeast-like } \\
\text { Pseudohyphae }\end{array}$ & Negative & Positive & Negative & C. neoformans ${ }^{d}$ \\
\hline 9 & M, 23 & AIDS & Liver & Paucireactive & $\begin{array}{l}\text { Nonencapsulated } \\
\text { yeast-like }\end{array}$ & Negative & Positive & Negative & C. neoformans ${ }^{d}$ \\
\hline \multirow[t]{2}{*}{10} & $\mathrm{M}, 10$ & AIDS & $\begin{array}{l}\text { Axillary } \\
\text { lymph node }\end{array}$ & Paucireactive & $\begin{array}{l}\text { Nonencapsulated } \\
\text { yeast-like in the } \\
\text { intercellular spaces }\end{array}$ & Negative & Positive & 1: $4096^{a}$ & C. gattii $^{c}$ \\
\hline & & & Brain & Paucireactive & $\begin{array}{l}\text { Nonencapsulated } \\
\text { yeast-like }\end{array}$ & Negative & Positive & & \\
\hline
\end{tabular}

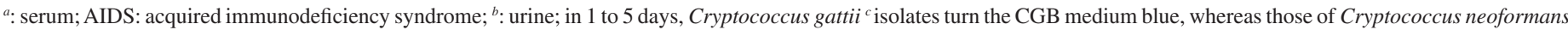
${ }^{d}$ do not; C: Cryptococcus; Cr Ag: Cryptococcal antigen; NA: not available.

yeasts (Fig. 3A). In other instances, several contiguous pseudohyphae demonstrated prominent branching. In cases 1-3, 5 and 7-10, the usual magenta color of the capsule after MM staining was absent (Fig. 3B).

When stained by FM, the black color in the cell wall of the organisms was disclosed. All the cases were positive - patients 4 and 6 presented classical micromorphological aspects in this yeast (Fig. 3C), while patients 1-3, 5 and 7-10 revealed a capsule-deficient form, confirming infection by Cryptococcus species (Fig. 3D).

\section{DISCUSSION}

As observed by others ${ }^{4}$, male patients predominated in our study. In the AIDS era, the relationship of cryptococcosis with gender distribution 


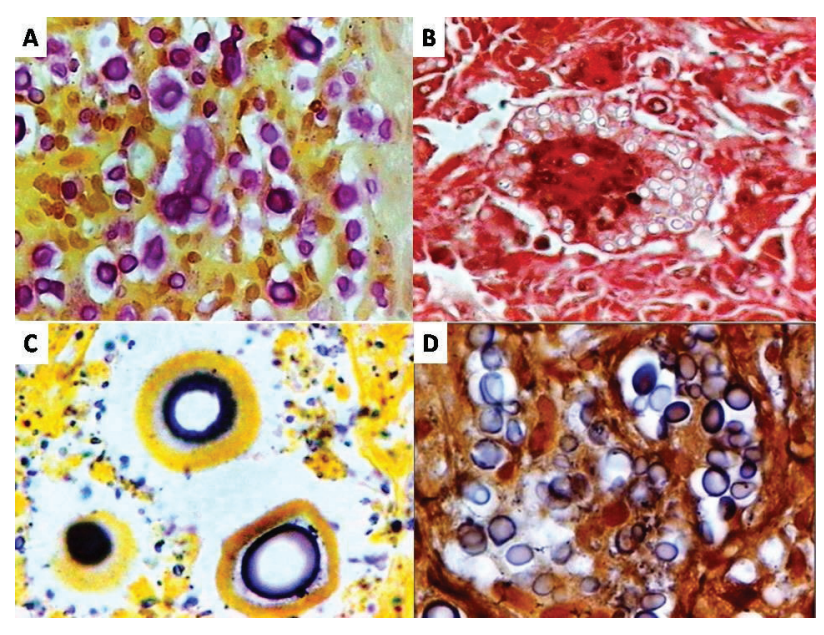

Fig. 3 - A, Cervical lymph node biopsy. Pseudohyphae demonstrating branching and numerous conventional yeast cells with the magenta capsules stained by Mayer's mucicarmine stain (case 6) (x 10). B, Lung tissue biopsy. The staining for capsular material is negative (case 8) (x 10). C, Left axillary tumor biopsy. Classical encapsulated fungal body of Cryptococcus (case 4) (x 100). D, Lung tissue biopsy. This special stain pattern is a characteristic of Cryptococcus, especially for the capsule deficient form. The black color in the walls of the organisms is disclosed by Fontana-Masson stain (case 1) (x100).

correlated to that of HIV infection ${ }^{17}$. Thus, the predominance of male patients reflects the predisposing conditions. The majority of patients were suffering from AIDS, supporting previous epidemiological studies which had reinforced that HIV infection was the main risk factor for cryptococcosis ${ }^{4}$. Consequently, diagnosis of cryptococcosis in patients with unknown predisposition always suggests an examination for HIV infection. The association with neoplastic and lymphoproliferative disorders ${ }^{16}$, and with organ transplantations ${ }^{26}$, has been well established.

The lungs are invariably the portal of entry, by inhalation from an environmental source, and also the initial site of infection for Cryptococcus spp. ${ }^{5,18}$. The infection can then spread via the bloodstream ${ }^{16}$. In these conditions, all areas of the body can be infected, including liver, lymph nodes, kidneys, adrenal glands and most notably the central nervous system $(\mathrm{CNS})^{18}$. According to the largest reported study of cryptococcosis in the AIDS era, five major sites can be involved that are particularly important in the diagnosis and management of cryptococcosis - the lungs, CNS, skin, prostate and eyes ${ }^{16}$.

Definitive diagnosis of cryptococcosis requires specific histopathological examination, detection of the cryptococcal antigen in body fluids by latex agglutination and identification of the yeast from cultures $^{8,28}$. Characteristic cryptococcal morphology does not pose any difficulty in recognizing the fungus ${ }^{7,8}$. However, unusual forms can give rise to a diagnostic dilemma ${ }^{23}$. Recognition of variants by morphology examination is important in the laboratory confirmation of the disease $\mathrm{e}^{7,25}$. In the current series, it is worthy of note that the cryptococcal cells had aberrant morphologies in about $1 / 3$ of our patients whose diagnosis was made histologically. Here, we have also highlighted that formalin fixation causes death of fungal agent preventing its growth on culture media.

Polysaccharide capsules are known to be a major cryptococcal virulence factor ${ }^{16}$. The loss of capsule material elicits an intense inflammatory response that includes early suppuration, phagocytosis and granuloma formation ${ }^{8,20,24}$. Previous reports described cryptococcosis caused nonencapsulated forms as extremely rare, and with no apparent incidence in humans ${ }^{3,9}$. In contrast, considering all of the features described above, a final diagnosis of capsule-deficient cryptococcosis was made in $80 \%(8 / 10)$ of our cases. The application of FM staining to the nonencapsulated forms of Cryptococcus was first reported by KWON-CHUNG et al. ${ }^{13}$, which identifies melanin pigments in the cell wall and selectively stains these yeasts in tissue specimens ${ }^{8}$. In our present series, an FM stain was an alternative diagnostic technique for the differentiation of the pathogenic fungal species, especially for distinguishing cryptococcal infection from the other fungal infections that can mimic it with their similar size and shape, tissue response and negative mucicarmine staining. In addition, detecting false-negative $\mathrm{CrAg}$ results is strongly associated to these poorly encapsulated cryptococcal cells as these strains do not produce enough polysaccharide antigens to be detected by the CrAg test. It is of note that patients with pulmonary disease without dissemination may have false-negative serum titres, since yeasts would not yet have spread from the lungs.

As previously noted, the appearance of Cryptococcus sp., a budding yeast cell, and the absence of pseudohyphae have been used as a point of differential diagnosis between cryptococcosis and candidiasis in several recent reviews that have discussed the histopathology of cryptococcal infection ${ }^{7,10}$. Other reports describe the identification of variant forms having pseudohyphae ${ }^{2,19}$, germ-tube like structures and hyphae-forming structures $^{6}$, all identified in an India ink preparation of CSF. In a review of prior necropsy specimens, a case was discovered in which germ tubes and hyphae were observed in brain tissues ${ }^{15}$. Rare germinating forms of Cryptococcus spp. have also been reported in a subcutaneous, erythematous nodule ${ }^{17}$. In 1971, a murine model study demonstrated hyphae-formation in 11 strains of this yeast ${ }^{21,22}$. Interestingly, BAVA et $a l^{2}$ concluded that the pseudohyphae should be considered a virulence factor and that great immunological deficit and further clinical evolution will better enable the fungal cells to produce atypical forms instead of the conventional yeast forms. In retrospect, KWON-CHUNG ${ }^{12}$ reported that the hyphal forms represented attempts of Cryptococcus to produce its sexual teleomorph, $F$. neoformans. However, some authors believe that although Cryptococcus rarely occurs in short chains resembling pseudohyphae, neither pseudohyphae nor true hyphae are presented ${ }^{12}$.

Our current series demonstrates the existence of the uncommon features such as pseudohyphae formation, chains of budding yeasts and structures resembling germ tubes during cryptococcal infection in humans. Awareness that Cryptococcus can form these features highlights the importance of special stains, such as mucicarmine ${ }^{7}$. In cases 4 and 6 , mucicarmine strongly stained the capsules of the individual yeasts, there were chains of budding yeasts, pseudohyphae and germ tube-like structures; all of which proved critical in histopathological diagnosis of the organisms as Cryptococcus rather than as a Candida-type species ${ }^{7,27}$. In addition, these histopathological findings, together with cryptococcal antigen detection by latex agglutination in sera and urine, and identification from the cultures, confirmed the Cryptococcus species infection in these two cases.

In summary, the current series emphasizes the importance of recognizing that cryptococcal cells do not always show typical encapsulated morphology, but may also be present as nonencapsulated yeast-like forms, pseudohyphae or germ tube-like structures, because 
generally this is not extensively described in the literature. In such instances, the association of HE and GMS preparations with MM and FM stains is useful for micromorphological diagnosis of cryptococcosis, as well as for identification of the uncommon forms of Cryptococcus species.

\section{RESUMO}

\section{Histopatologia, sorologia e cultivo no diagnóstico da criptococose}

A criptococose é a mais comum infecção fúngica oportunística observada em pacientes com síndrome da imunodeficiência adquirida (AIDS). Relatamos 13 casos da infecção baseados no diagnóstico histopatológico, sorológico e cultivo. Foram analisadas: a epidemiologia, as técnicas histoquímicas básicas de hematoxilina-eosina (HE) e coloração pela prata (GMS), bem como as técnicas histoquímicas especiais de mucicarmim de Mayer (MM) e Fontana-Masson (FM), o teste do antígeno criptocóccico ( $\mathrm{CrAg}$ ) e o isolamento em cultivos em ágar-Sabouraud (SAB), ágar infusão de cérebro-coração (BHI) e meio com canavanina azul de bromotimol (CGB). Em quatro casos, resultados tintoriais insatisfatórios pela coloração de MM associados a títulos negativos pelo teste do CrAg, a coloração de FM confirmou a infecção pelo Cryptococcus deficiente de cápsula. Oito isolados foram identificados: seis casos apresentaram a infecção por Cryptococcus neoformans e dois casos apresentaram a infecção por Cryptococcus gattii.

\section{ACKNOWLEDGEMENTS}

This work was supported by a grant from the Coordenação de Pessoal de Nível Superior (CAPES, Brasília, BEX: 0060/09-7).

\section{REFERENCES}

1. Alfonso F, Gallo L, Winkler B, Suhrland MJ. Fine needle aspiration cytology of peripheral lymph node cryptococcosis. A report of three cases. Acta Cytol. 1994;38:459-62.

2. Bava J, Solari R, Isla G, Troncoso A. Atypical forms of Cryptococcus neoformans in CSF of an AIDS patient. J Infect Dev Ctries. 2008;2:403-5.

3. Cheon WS, Eom KS, Yoo BK, Jang SH, Bahn JW, Kim DG, et al. A case of pulmonary cryptococcosis by capsule-deficient Cryptococcus neoformans. Korean J Intern Med. 2006;21:83-7.

4. Dromer F, Mathoulin-Pelissier S, Fontanet A, Ronin O, Dupont B, Lortholary O, et al Epidemiology of HIV-associated cryptococcosis in France (1985-2001): comparison of the pre- and post-HAART eras. AIDS. 2004;18:555-62.

5. Feldmesser M, Kress Y, Casadevall A. Dynamic changes in the morphology of Cryptococcus neoformans during murine pulmonary infection. Microbiology. 2001;147:2355-65.

6. Freed ER, Duma RJ, Shadomy HJ, Utz JP. Meningoencephalitis due to hyphaeforming Cryptococcus neoformans. Am J Clin Pathol. 1971;55:30-3.

7. Gazzoni AF, Severo CB, Barra MB, Severo LC. Atypical micromorphology and uncommon location of cryptococcosis: a histopathologic study using special histochemical techniques (one case report). Mycopathologia. 2009;167:197-202.

8. Gazzoni AF, Pegas KL, Severo LC. Histopathological techniques for diagnosing cryptococcosis due to capsule-deficient Cryptococcus: case report. Rev Soc Bras Med Trop. 2008;41:76-8.
9. Kanazawa M, Ishii M, Sato Y, Kitamura K, Oshiro H, Inayama Y. Capsule-deficient meningeal cryptococcosis. Acta Cytol. 2008;52:266-8.

10. Kimura M, Furuta T, Teramura K, Satou T. Pseudohyphae of Cryptococcus in a cytologic specimen. Acta Cytol. 1998;42:817-8.

11. Kwon-Chung KJ. A new genus, filobasidiella, the perfect state of Cryptococcus neoformans. Mycologia. 1975;67:1197-200.

12. Kwon-Chung KJ, Bennett JE. Medical Mycology. Philadelphia: Lea \& Febiger; 1992.

13. Kwon-Chung KJ, Hill WB, Bennett JE. New, special stain for histopathological diagnosis of cryptococcosis. J Clin Microbiol. 1981;13:383-7.

14. Lin X. Cryptococcus neoformans: morphogenesis, infection, and evolution. Infect Genet Evol. 2009;9:401-16.

15. Lurie HI, Shadomy HJ. Morphological variations of a hypha-forming strain of Cryptococcus neoformans (Coward strain) in tissues of mice. Sabouraudia. 1971;9:104.

16. Mitchell TG, Perfect JR. Cryptococcosis in the era of AIDS - 100 years after the discovery of Cryptococcus neoformans. Clin Microbiol Rev. 1995;8:515-48.

17. Moore M. Cryptococcosis with cutaneous manifestations. Four cases with a review of published reports. J Invest Dermatol. 1957;28:159-82.

18. Moretti ML, Resende MR, Lazéra MS, Colombo AL, Shikanai-Yasuda MA et al. Consenso em criptococose - 2008. Rev Soc Bras Med Trop. 2008;41:524-44

19. Paschoal RC, Melhem MSC, Guelli T, Szeszs MW. Células atípicas de Cryptococcus neoformans var. neoformans observadas em líquido cefalorraquidiano. Rev Inst Adolfo Lutz. 2007;66:78-80.

20. Schwartz DA. Characterization of the biological activity of Cryptococcus infections in surgical pathology. Ann Clin Lab Sci. 1988;18:388-97.

21. Shadomy HJ, Utz JP. Preliminary studies on a hyphaforming mutant of Cryptococcus neoformans. Mycologia. 1966;58:383-90.

22. Shadomy HJ, Lurie HI. Histopathological observations in experimental cryptococcosis caused by a hypha-producing strain of Cryptococcus neoformans (Coward strain) in mice. Sabouraudia. 1971;9:6-9.

23. Shashikala, Kanungo R, Srinivasan S, Mathew R, Kannan M. Unusual morphological forms of Cryptococcus neoformans in cerebrospinal fluid. Indian J Med Microbiol. 2004;22:188-90

24. Shibuya K, Coulson WF, Wollman JS, Wakayamam M, Ando T, Oharaseki T, et al. Histopathology of cryptococcosis and other fungal infections in patients with acquired immunodeficiency syndrome. Int J Infect Dis. 2001;5:78-85

25. Sugiura Y, Homma M, Yamamoto T.Difficulty in diagnosing chronic meningitis caused by capsule-deficient Cryptococcus neoformans. J Neurol Neurosurg Psychiatry. 2005;76:1460-1

26. Sun HY, Wagener MM, Singh N. Cryptococcosis in solid-organ, hematopoietic stem cell, and tissue transplant recipients: evidence-based envolving trends. Clin Infect Dis. 2009; 48:1566-76.

27. Williamson JD, Silverman JF, Mallak CT, Christie JD. Atypical cytomorphologic appearance of Cryptococcus neoformans. A report of five cases. Acta Cytol. 1996;40:363-70

28. Xavier MO, Oliveira FM, Severo LC. Laboratory diagnosis of pulmonary mycoses J Bras Pneumol. 2009;35:907-19.

Received: 15 October 2009

Accepted: 9 March 2010 